PIOTR MARCINIAK

Faculty of Architecture

Poznan University of Technology

\title{
Polska Kronika Filmowa as a source for research on contemporary Polish architecture
}

\begin{abstract}
Marciniak Piotr, Polska Kronika Filmowa as a source for research on contemporary Polish architecture. "Images" vol. XXII, no. 31. Poznań 2017. Adam Mickiewicz University Press. Pp. 21-28. ISSN 1731-450X. DOI 10.14746/i.2017.31.03.

The materials used by architectural historians to research the post-war period are very limited, and the available archive resources are incomplete and dispersed. In this context, of special significance are other forms of visual materials that documented the spatial reality of the communist period. Documentary films, and in particular the Polska Kronika Filmowa [Polish Film Chronicle] newsreel, can make an an important contribution to and a resource for historical research on contemporary Polish architecture.

This text contains methodological reflections on the role of film studying the history of contemporary architecture. It describes the new research options, including the ability to recreate original spatial phenomena, and also the contemporary techniques and technology as well as the educational dimension of the Polish Film Chronicle. In this context, it is especially interesting to compare the documentary material from the Chronicle with other archival material, e.g. drawings, plans and photographs. This method provides an additional opportunity for a fuller and more objective recreation of space in 3D. This "reverse modelling" can be used to restore or preserve the original condition of structures, or even to rebuild ones no longer existing.
\end{abstract}

KEYwords: Polska Kronika Filmowa [Polish Film Chronicle], architecture, town planning, history, methodology

Systematic research on post-war Polish architecture did not begin until the early twenty-first century.[1] The available resources used by architectural historians to investigate the post-war period, and in particular the period of Polska Rzeczpospolita Ludowa (Polish People's Republic, PRL; 1952-1989) are quite limited. The basic materials available to researchers are, unfortunately, incomplete. The contents of Polish archives are negligible, whilst the materials and resources from the former state-run large-scale design studios are largely inaccessible due to their systematic destruction. Consequently, architectural historians also use other sources and archival materials in their research. An indispensable source of knowledge about the period in question is provided by texts published in major magazines of the time, containing materials of high

[1] This refers to systematic research conducted from a historical perspective. Before 1989, several important works were published, e.g. A. Kotarbiński, Rozwój urbanistyki i architektury polskiej w latach 1944-1964, Warszawa 1967; Budownictwo i architektura w Polsce 1945-1966, ed. J. Zachwatowicz, Warszawa
Images vol. XXII/no. 31 Special Issue Poznań 2017 ISSN 1731-450X 
factual value. Polish architectural and urban planning journalism was based on several key titles that shaped the opinion of the scientific and creative milieus.[2] In communist Poland, periodicals devoted to architecture were already being published during the early post-war years. There were also several trade and academic journals, in addition to some minor titles. Obviously, all these magazines were financed by the state, which also had complete control of the published content. Nonetheless, the great importance of these periodicals in documenting spatial phenomena in the PRL, and also in presenting views and theoretical discussions, as well as in architectural education is indisputable. They remain a valuable source of knowledge, and also bear testimony to a bygone era.[3] However, these are still insufficient; hence, recent years have witnessed the emergence of research based on new techniques and methods, for example oral history. Researchers are also keen to use other available resources, including archival film footage, especially Polska Kronika Filmowa [Polish Film Chronicle, PKF] whose available instalments contain a significant amount of material that is of great assistance to architectural historians. It can even be argued that documentaries, and in particular Polska Kronika Filmowa, are an important contribution to and a resource for historical research on contemporary Polish architecture, especially architecture from the PRL period.

Polska Kronika Filmowa was a newsreel which was first created in Lublin in 1944, and which went on to record the entire communist period, as well as the early years of democratic Poland. The last instalment was filmed in 1994 (50 years after the Chronicle's inception). Obviously, the PKF was a medium used for propaganda and it was heavily censored. Its main task was to embellish the activities of the authorities and to win over public opinion. Nonetheless, the actual documentary material, which used all sorts of means of persuasion, is a most effective resource for "evidencing the subject matter".[4] As such, it can become an abundant supply of archival records relating to architecture and urban planning in the PRL.

The material which can assist architectural researchers is, indeed, extensive. The Polska Kronika Filmowa collection contains over four thousand films from the years 1944-1994. These include a wide variety of records: newsreels, trade series and special editions, as well as a great amount of footage that was not screened.[5] In addition, the PKF news-

[2] It should be noted that the origins of architectural magazines in Poland date back to 1875 , when the weekly "Przegląd Techniczny”, published in Kraków, began printing regular features on the subject. In 1900, the monthly magazine "Architekt" was introduced and during the Interbellum, over a dozen titles were published, including the most authoritative one, "Architektura i Budownictwo" (compare "Architektura" 1977 , no. 9-10, p. 3).
[3] The subject of written resources has been discussed in detail in: P. Marciniak, "Reading and Writing Architecture. Polish Architectural Magazines (1945-1989)," Printed in Red. Architectural Writings during Communism. "studies in History and Theory of Architecture" 2013, no. 1, p. 21-29.

[4] M. Przylipiak, Poetyka filmu dokumentalnego, Gdańsk 2000, p. 11.

[5] M. Cieśliński, Piękniej niż w życiu: Polska Kronika Filmowa 1944-1994, Warszawa 2006, p. 13. 
reel shows were usually followed by supplements in the form of short films (documentaries or drama). Some twenty thousand of these films were produced in the PRL to be shown at cinemas. [6]

At this point, it is important to mention other Polish film archives, for instance the National Film Archive, the National Digital Archives, the archives of Wytwórnia Filmów Dokumentalnych i Fabularnych [Documentary and Feature Film Studios] and Wytwórnia Filmów Oświatowych [Educational Film Studios], as well as of the Łódź Film School and Film Museum. Among these, the Polish Film Chronicle is an example of a very good and easily available, albeit unutilised resource, which could provide interesting and valuable material for architects, art historians and architectural historians (film researchers do not need to be convinced).

Scholarly interest in film as a historical source does not require clarifying and already has its own history. The first person who drew attention to film as a new source of history was a Pole, Bolesław Matuszewski, who in a work called Une nouvelle source d'histoire [A New Source of History], published in 1898 in Paris, concluded that live photography would become a method of studying the past.[7] Marc Ferro, the author of the excellent work Cinema and History, wrote that "a film", be it an image of reality or not, document or fiction, authentic plot or pure invention, is History." [8] He also mentions two basic aspects of this issue: the historical interpretation of a film and the interpretation of history by cinematography. Moreover, in his perception of the film document, Ferro points out that film conveys an image whose significance extends beyond the cinematographic, which is apparent not only in the case of newsreels, but also in feature films. [9]

The concept of researching films as historical documents and sources is not a new one. It was outlined in the 1960s and initially it met with resistance from many researchers. Even today, many historians remain sceptical about using film sources in their research, claiming that the language of cinematography is opaque and difficult to interpret. In Poland, arguments like this were already raised in the 1970s, for instance by Helena Karczowa, who wrote about filmed reportage and newsreels as a historical source.[10] It seems, however, that in Polish historiography film has secured its rightful place as a research source after the release of the book Film jako źródło historyczne.[11] This outstanding work, which regards film as part of historical culture, is

[6] A. Żurawicz Kinematografia w Polsce, "Wiadomości Statystyczne" 2010, no. 7, pp. 23-36.

[7] B. Matuszewski, Une nouvelle source d'histoire Nowe źródło historii, Warszawa 1955.

[8] M. Ferro, Kino i historia, Warszawa 2011, p. aa. [9] Idem, Le film. Une contre-analyse de la société?, in: Faire de l'histoire, eds. J. Le Goff, P. Nora, Vol. 3, Paris 1974; Polish translation: M. Ferro, Film. Kontranaliza społeczeństwa? in: Film i historia. Antologia, ed. I. Kurz, Warszawa 2008, pp. 67-92. These themes have also been elaborated by other researchers, for example M. Fantoni Minnella, Habemus Nanni: lessico morettiano: architettura di un autore, Parma 2015, p. $1-95$.

[10] H. Karczowa, Reportaż filmowy i kronika jako źródło historyczne, "Studia Źródłoznawcze" 1971, no. 16 .

[11] M. Hendrykowski, Film jako źródło historyczne, Poznań 2000. 
a methodological attempt at organising the problems that emerge in research on the image as a source of cognition.

Naturally, no documentary footage can guarantee objective truth. In the case of newsreels, one of their components, the image, is a faithful record of reality (albeit it can contain staged fragments, which is an important issue in the context of the need to reject false sources). Newsreels are a type of information about current national and international events. They typically combine a number of different themes into a single whole, whilst the particular topics are communicated in a fragmentary manner and information is rendered more concise due to the specific time limits. The major theme, also a component of a newsreel, reflects real events and real people, and is a small format of filmed reportage.[12] Nonetheless, to architectural researchers, it is the image contained in the Polska Kronika Filmowa that is the primary carrier of meaning and references. Clearly, in methodological reflections on the importance of film to research on the contemporary history of architecture it is necessary to apply a dose of philosophical scepticism. This approach, in which a prerequisite for philosophical reflection is, according to Oakeshott, an ability and determination to constantly obtain new points of view whilst discarding previous ones, is not so much a cumbersome obstacle, but rather "an extreme ideal of certainty" that provides a better chance of objective cognition. [13]

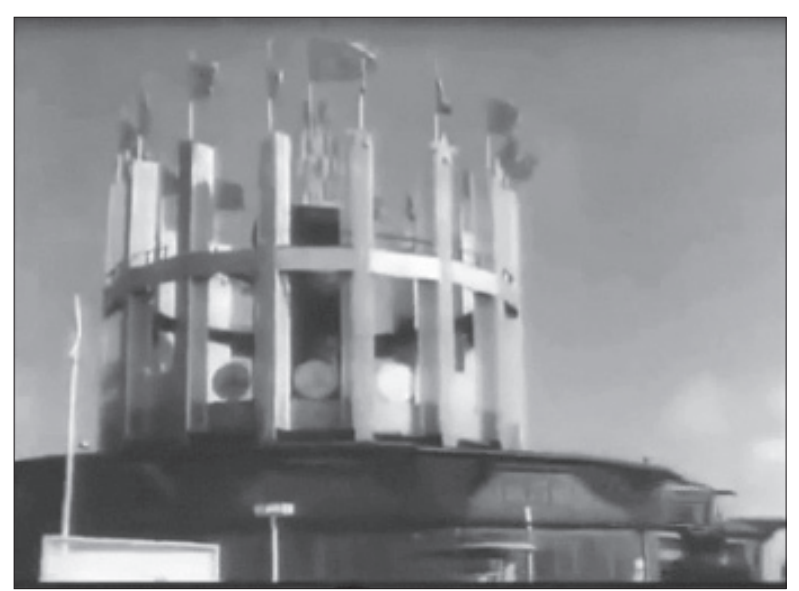

Il. 1. Polska Kronika Filmowa: reverse modelling - USSR Pavilion at the Poznań International Fair (source: PKF 18/49, still)

The material contained in the PKF newsreels is very extensive, but also highly diversified thematically. It covers many issues, including politics, society, economics, culture and sports. Throughout the duration of the PRL, documentaries were used to record all the important events in Poland's political, economic and cultural life, and in this respect, the PKF played a particular role.[14] This massive resource can be used to discover images of architecture, town planning, technology and industrial design. This is certainly a laborious task, but some of the research tropes are very promising. [15]

More than any other fields, the history of architecture and urban planning sees image, apart from text, as an important element of studying and describing reality. Iconographic sources in particular supplement the discourse on the history of contemporary architecture. The authenticity criterion of the source takes into account knowledge of the time and place of its creation, its

[12] H. Karczowa, op.cit.

[13] D. Leszczyński, Zdrowy rozsądek i sceptycyzm, "Roczniki Filozoficzne" 2011, p. 24.

[14] J. Bocheńska, Film dokumentalny, Polski film krótkometrażowy w 25-leciu PRL, Warszawa 1969, pp. 6-14.
[15] For example, PKF 12A/72, which presents the trade fairs in Poznań and Cairo, and may provide an opportunity to study the renowned albeit undocumented Tropik exhibition pavilion designed by J. Sołtan, Z. Ihnatowicz and W. Zalewski in 1955. 
pragmatic authenticity which depends on the research conducted and the questions posed to the source, as well as whether it is accurate and original.[16] Regarding each of these aspects, the images contained in the PKF satisfy the requirements of historical sources. On the other hand, regarding historians' major areas of interest in film (as indicated by, for example, O'Connor), one should emphasize the Chronicle's importance as a historical source aimed at providing information about specific events (in the case of architectural historians, this means information about the recording of space). The PKF newsreels do, of course, include staged scenes. However, these relate primarily to various types of social events and not "set design." Even if it does provide a backdrop, the architecture in such scenes for staged footage, is obviously, original.

Besides the recording of events or images, an extremely important aspect of the PKF pertains to the categories that are relevant to the study of architecture. Many instalments of the Chronicle focus directly on the subject of architecture, urban construction, construction technologies and interior furnishing. In this case, the analysis of the source material, burdened with a propaganda narrative, must be carried out only on the visual layer. The proper interpretation of this layer must be recorded in the form of a written retrospection. [17] Nevertheless, such an analysis does provide for identifying of a number of exciting new research dimensions, with at least four interesting research options.

The first of these options is the ability to recreate the original spatial phenomena. Naturally, the Polska Kronika Filmowa is not a direct document, but a kind of "distorting mirror" of communist reality. To conduct a factual analysis, it is necessary to first remove the propaganda layer in order to reveal what is of the greatest value to the architectural historian, namely space. Within this space, the PKF films reflect something that is inestimable: the ambience of streets and the relations between people. The materials contained in the newsreels also offer a unique opportunity to see the streets in the dimensions in which they were designed, with the maximum traffic calculated at that time, for example PKF 25A/72, which shows Święty Marcin Street in Poznań. The films also provide an opportunity to see public space in its original form, with a minimum count of cars, for example PKF 35/65 showing space within housing complexes in Warsaw.

The second option relates to the studying of the techniques and

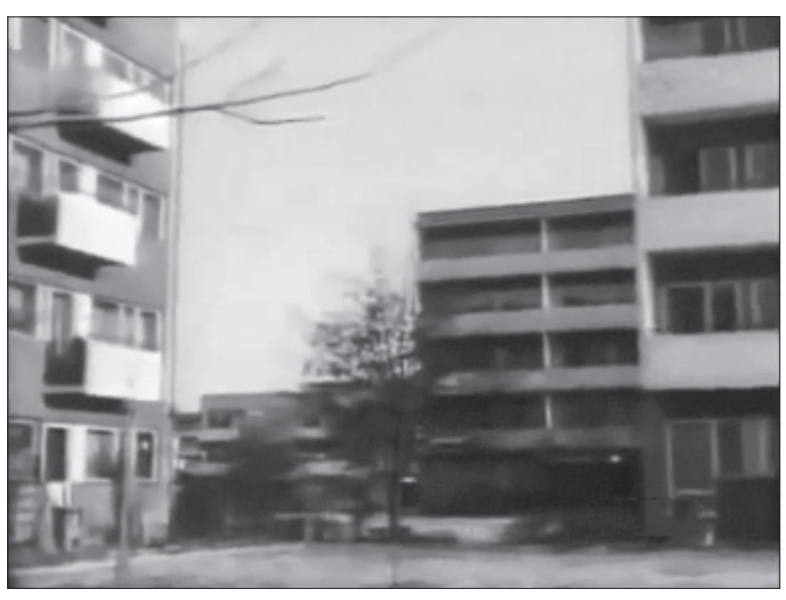
Il. 2. Polska Kronika Filmowa: recreation of spatial phenomena - space and ambience in housing projects in Warsaw (source: PKF 35/65, still) technologies used in the post-war period. It should be noted that, from its very beginning, the Polska Kronika Filmowa eagerly documented all 
the post-war construction work, from the removal of debris in Warsaw, Poznan and Wrocław, to the construction of new industrial plants. In the 1970s, a "trend towards ties with life" emerged, which consisted in depicting modernity and an interest in technology. In accordance with the official policy of the era, the PKF placed great emphasis on documenting events, and also the social and economic transformation. [18] The opportunity to look at the technology and solutions of the time from today's perspective enhances our understanding of the communist reality, as well as the origins and circumstances of specific projects. A good example to illustrate this point is the production of prefabricated concrete slabs in the so-called "home factories", which is difficult to comprehend from the point of view of today's technology, or the equally interesting proposals for residential interiors and the furniture system called meble Kowalskich (furniture designed by the Kowalski designer couple / furniture for the Joneses).[19]

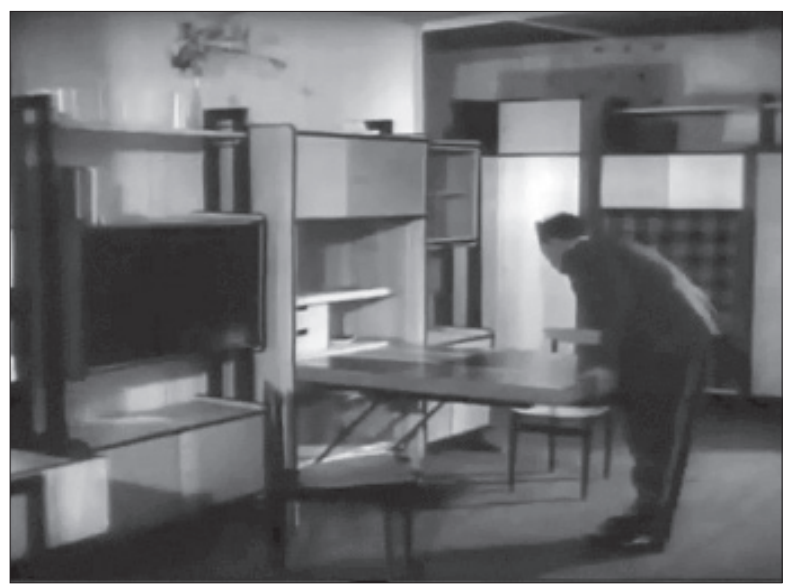

Another important option offered by the Polish Film Chronicle is its educational value, which is embedded in the opportunity to interpret and understand the context of the time not only from the visual point of view, but also from that of the audio layer. The combination of images and words perfectly convey (or effectively recreate) the atmosphere of the PRL. No words are enough to describe the ideological narrative and the propaganda dimension not just of the newsreel, but also of the whole contemporary reality. From the hermeneutic and historical perspective, this

Il. 3. Polska Kronika Filmowa: a source of information about technology - interiors and meble Kowalskich (source: PKF $13 \mathrm{~A} / 61$, still) is one of the most important research sources, as exemplified by illustrations from the state-run design studios or the social aspect and ambience of contemporary streets.

One more interesting option is the ability to combine different sources using the "reverse modelling" method.[20] The PFK is a huge resource of historical documentation, since one of its priorities was to focus on the post-war reconstruction and on development in the Recovered Territories. The footage created at the time shows not only Warsaw, but also other cities, including Łódź, Poznań, Gdynia and Katowice. Moreover, in later years, during the period of Edward Gierek's "propaganda of success", the newsreels showed the developing country, for example the series Kroniki XXX-lecia [Chronicles of the Three Decades].
[18] M. Cieśliński, op.cit., pp. 119-121.

[19] This furniture has been described by authors like

J. Kowalski (J. Kowalski, Meble Kowalskich. Ludzie i rzeczy. Dębogóra 2014); however, the opportunity to see the actual "flexible" solutions constitutes an invaluable supplement to even the best monographic publication.
[20] "Reverse modelling" is a term introduced for the purpose of this text. It describes the author's original method based on the associating of moving images with other archival materials, and resulting in full spatial imaging options.

[21] W. Orliński, Metropolis zmienia kino i świat, "Gazeta Wyborcza” 2008, 4 April, p. 14. 
In this context, it is extremely interesting to compare the documentary material from the Polish Film Chronicle (or from other films) with other archival materials like drawings, plans or photographs. This method allows for a fuller and more objective recreation of space from the past in $3 \mathrm{D}$. Such reverse modelling could find a practical application in the restoration or preservation of the original condition of structures, or even in the rebuilding of those that no longer exist. This can be illustrated by a photograph of the Spodek Sports and Entertainment Hall in Katowice (by Maciej Gintowt and Maciej Krasiński) or the no longer extant

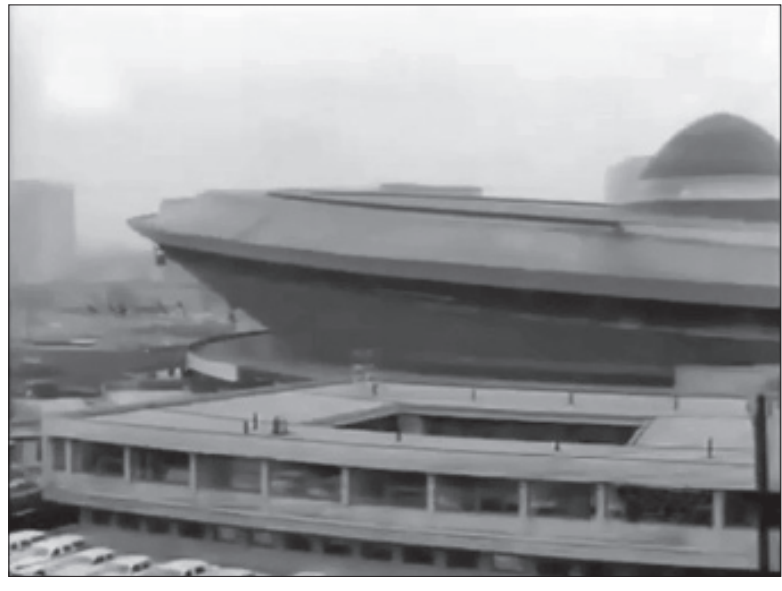

Il. 4. Polska Kronika Filmowa: reverse modelling - Spodek Sports and Entertainment Hall in Katowice (source: PKF $19 \mathrm{~A} / 71$, still)

B I B L I O G R A P H Y

Bocheńska J., Film dokumentalny, Polski film krótkometrażowy w 25-leciu PRL, Warszawa 1969

[22] Polska Kronika Filmowa: the resources which are not available for screening and have not been processed constitute several hundred instalments. 
Budownictwo i architektura w Polsce 1945-1966, ed. J. Zachwatowicz, Warszawa 1968

Cieśliński M., Piękniej niż w życiu: Polska Kronika Filmowa 1944-1994, Warszawa 2006

Fantoni Minnella M., Habemus Nanni: lessico morettiano: architettura di un autore, Parma 2015, pp. 1-95

Ferro M., Kino i historia, Warszawa 2011

Ferro M., Le film. Une contre-analyse de la société?, in: Faire de l'histoire, eds. J. Le Goff, P. Nora, Vol. 3, Paris 1974; Polish translation: M. Ferro, Film. Kontranaliza społeczeństwa? in: Film i historia. Antologia, ed. I. Kurz, Warszawa 2008, pp. 67-92

Hendrykowski M., Film jako źródło historyczne, Poznań 2000

Karczowa H., Reportaż filmowy i kronika jako źródło historyczne, "Studia Źródłoznawcze" 1971, no. 16

Kotarbiński A., Rozwój urbanistyki i architektury polskiej w latach 1944-1964, Warszawa 1967

Kowalski J., Meble Kowalskich. Ludzie i rzeczy, Dębogóra 2014

Leszczyński D., Zdrowy rozsądek i sceptycyzm, "Roczniki Filozoficzne" 2011, pp. $5-34$

Marciniak P., Reading and Writing Architecture. Polish Architectural Magazines (1945-1989), in: Printed in Red. Architectural Writings during Communism, "Studies in History and Theory of Architecture" 2013, no. 1, pp. 21-29

Matuszewski B., Une nouvelle source d'histoire - Nowe źródło historii, Warszawa 1955

Orliński W., Metropolis zmienia kino i świat, "Gazeta Wyborcza” 2008, 4 April

Przylipiak M., Poetyka filmu dokumentalnego, Gdańsk 2000

Szafer T.P., Nowa architektura polska. Diariusz lat 1966-1970, Warszawa 1972

Szafer T.P., Nowa architektura polska. Diariusz lat 1971-1975, Warszawa 1979

Szafer T.P., Nowa architektura polska. Diariusz lat 1976-1980, Warszawa 1981

Topolski J., Metodologia historii, Warszawa 1973

Topolski J., Teoria wiedzy historycznej, Poznań 1983

Żurawicz A. Kinematografia w Polsce, "Wiadomości Statystyczne" 2010, No. 7, pp. 23-36. 